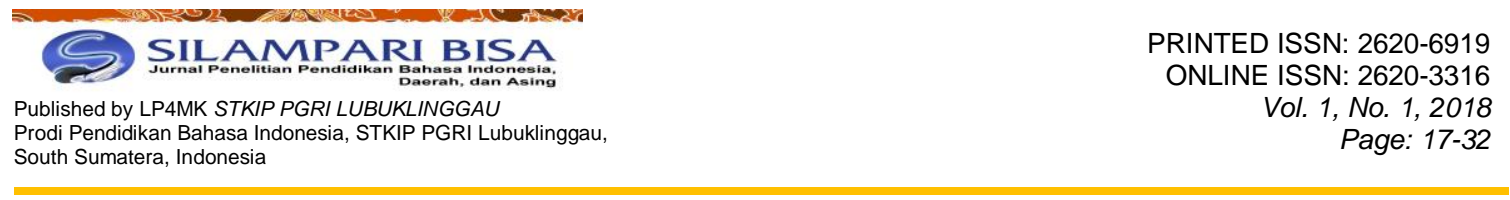

\title{
TINDAK TUTUR EKSPRESIF DALAM FILM KEHORMATAN DI BALIK KERUDUNG SUTRADARA TYA SUBIAKTO SATRIO
}

\author{
Sri Murti ${ }^{1}$, Nur Nisai Muslihah ${ }^{2}$, \& Intan Permata Sari ${ }^{3}$ \\ 1,2,3Program Studi Pendidikan Bahasa dan Sastra Indonesia, \\ STKIP PGRI Lubuklinggau \\ JIn. Mayor Toha Kelurahan Air Kuti, Kota Lubuklinggau, 31628, Indonesia \\ Email: srimurti05@gmail.com, nurnisai@yahoo.co.id
}

Submitted: 29-April-2018 Accepted : 22-June-2018
Published: 23-June-2018

DOI: 10.31540/silamparibisa.v1i1.7 URL: https://doi.org/10.31540/silamparibisa.v1i1.7

\begin{abstract}
Abstrak
Film Kehormatan di Balik Kerudung dengan sutradara Tya Subiakto Satrio merupakan film berisi percintaan, kesedihan, dan kesetiaan sehingga sangatlah menarik dan bisa dijadikan sebagai contoh dalam pembelajaran novel di sekolah. Tujuan penelitian ini untuk mendeskripsikan tindak tutur ekspresif dalam film Kehormatan di Balik Kerudung. Metode penelitian menggunakan metode deskriptif kualitatif. Teknik pengumpulan data yang digunakan yaitu teknik dokumentasi. Teknik analisis data berupa tahap deskrpsi, klasifikasi, analisis, interpretasi data, evaluasi, dan kesimpulan. Hasil penelitian ini menunjukkan bahwa tindak tutur ekspresif dalam film Kehormatan di Balik Kerudung terdiri atas tindak tutur ekspresif berupa: a) memuji dalam konteks: memuji kecantikan dan ketampanan yang dimiliki petutur, dan terkesan dengan pakain dan wewangian yang petutur kenakan; b) mengucapkan terima kasih dengan ciri: mengucapkan terima kasih karena perbuatan baik yang sudah dilakukan petutur, mengucapkan terima kasih atas kenikmatan yang Allah berikan, dan mengucapkan terima kasih karena merasa merepotkan; c) mengucapkan maaf dengan ciri: karena telah mengecewakan petutur, karena tidak menepati janji, mengucapkan maaf atas perlakuan kasar dan tidak menyenangkan, serta berbuat kesalahan; d) kebahagiaan dengan ciri: situasi yang membuat nyaman, bersyukur atas apa yang dimiliki, tersenyum indah, saling menyukai, dan orang tua yang dikaruniai anak; serta e) mengeluh dalam konteks: perasaan sedih karena ditinggal menikah, perasaan sakit karena dilarang menikah, dan dikecewakan, diberi cobaan atau halangan dan rintangan. Dengan demikian, tindak tutur ekspresif dalam film Kehormatan di Balik Kerudung terdiri atas tindak tutur ekspresif dalam bentuk memuji, ucapan terima kasih, ucapan permohonan maaf, kebahagiaan, dan tindakan mengeluh.
\end{abstract}

Kata kunci: tindak tutur, tindak tutur ekspresif, film

\section{EXPRESSIVE ACTION \\ IN THE FILM KEHORMATAN DI BALIK KERUDUNG DIRECTOR TYA SUBIAKTO SATRIO}

\begin{abstract}
The film Kehormatan di Balik Kerudung with director Tya Subiakto Satrio is a film about love, sadness and fidelity so it is very interesting and can be used as an example in novel learning in school. The objective of the study was to describe expressive speech acts in the film Kehormatan di Balik Kerudung. The research method used qualitative descriptive method. Data collection techniques used are documentation techniques. Data analysis techniques are deskrpsi, classification, analysis, data interpretation, evaluation, and conclusion. The results of this study indicate that expressive
\end{abstract}


speech acts in the film Kehormatan di Balik Kerudung consists of expressive speech acts in the form of: a) praising in the context of: praising the beauty and handsomeness of the opponent said, and impressed by the clothes and fragrances that the opponent said wearing; b) expressing gratitude with the trait: thanking you for the good deeds the opponent has done, thanking you for the pleasures God has given, and thanking him for the inconvenience; c) to apologize with the trait: to have disappointed the opponent, for not keeping promises, to apologize for abuse and discomfort, and to make mistakes; d) happiness with features: situations that make you comfortable, grateful for what you have, beautiful smiles, mutual love, and parents who are blessed with children; and e) complain to the context: the sadness of being married, the pain of being forbidden to marry, and being let down, given trials or hindrances and obstacles. Thus, the expressive act of expressiveness in the film Kehormatan di Balik Kerudung consists of expressive speech acts in the form of praise, thanksgiving, apology, happiness, and complaining.

Keywords: speech action, expressive speech acts, film

\section{A. Pendahuluan}

Bahasa sangat berperan penting dalam kegiatan interaksi sesama manusia di dalam masyarakat. Dengan bahasa, kita dapat berkomunikasi dengan sesama tanpa ada paksaan dari orang lain. Bahasa dapat juga digunakan sebagai alat untuk mengutarakan sesuatu kepada orang lain, mengekspresikan kepentingannya, ataupun mempengaruhi orang lain sehingga orang tersebut mengerti keinginan kita. Bahasa merupakan sebuah kunci utama dalam hal berkomunikasi yang dimiliki dan digunakan oleh manusia untuk berinteraksi dengan sesama di sekitar lingkungan hidupnya. Eksistensi bahasa hampir meliputi segala bidang kehidupan karena segala sesuatu yang dihayati, dialami, dirasakan, dan dipikirkan oleh seseorang hanya dapat diketahui orang lain jika telah diungkapkan dengan bahasa.

Perlu disadari bahwa komunikasi merupakan suatu proses penyampaian pesan yang berlangsung, apabila antara penutur dan mitra tutur (petutur) memiliki kesamaan makna tentang pesan yang dikomunikasikan tersebut. Kesamaan makna antara penutur dan mitra tutur tersebut sangat bergantung pada konteks tuturan. Artinya, makna sebuah tuturan akan berbeda dengan konteks tuturannya berbeda.

Tutur atau tindak tutur merupakan bagian dari kajian ilmu bahasa yaitu pragmatik.

Pragmatik merupakan studi tentang hubungan antara bentuk-bentuk linguistik dan pemakai bentuk-bentuk tersebut (Yule, 2006:5). Sejalan dengan pendapat di atas menurut Levinson (1983:7), pragmatik yaitu kajian suatu bahasa dari perspektif fungsional yang berusaha menjelaskan beberapa aspek struktur linguistik dengan mengacu pada beberapa pengaruh dan gejala non-linguistik. Secara umum kajian pragmatik meliputi pragmalinguistik dan sosiopragmatik. 
Pragmalinguistik adalah telaah mengenai kondisi-kondisi umum penggunaan komunikatif bahasa. Pragmalinguistik dapat diterapkan pada telaah pragmatik yang tujuannya mengarah pada tujuan linguistik, di mana mempertimbangkan sumbersumber khusus yang disediakan oleh suatu bahasa terbentuk untuk menyampaikan ilokusi-ilokusi tertentu. Sedangkan Menurut Yule (2006:25), sosiopragmatik adalah telaah mengenai kondisi-kondisi 'setempat' atau kondisi-kondisi 'lokal' yang lebih khusus mengenai penggunaan bahasa, kondisi tersebut merupakan konteks dari sebuah tuturan. Masyarakat setempat lebih khusus terlihat bahwa prinsip kooperatif atau prinsip kerja sama dan prinsip kesopansantunan berlangsung secara berubahubah dalam kebudayaan yang berbeda-beda, di antara kelas-kelas sosial yang berbeda-beda, aspek-aspek, dan sebagainya.

Menurut Yule (2006:82) tindak tutur merupakan tindakan-tindakan yang ditampilkan lewat tuturan. Pada suatu saat, tindakan yang ditampilkan dengan menghasilkan suatu tuturan akan mengandung tiga tindakan yang saling berhubungan. Pertama adalah tindak lokusi, yang merupakan tindak dasar tuturan atau menghasilkan suatu ungkapan linguistik yang bermakna. Kedua, tindak tutur ilokusi ditampilkan melalui penekanan komunikatif suatu tuturan. Ketiga, tindak perlokusi ialah menuturkan dengan asumsi bahwa pendengar akan mengenali akibat yang ditimbulkan.

Selanjutnya, Chaer (2010:29-30) membagi tindak tutur ilokusi menjadi lima kategori yaitu deklaratif, refresentatif, ekspresif, direktif, dan komisif. Ekspresif yaitu tindak tutur jenis ini mencerminkan pernyataan-pernyataan psikologis dan dapat berupa tindak tutur ekspresif memuji, mengucapkan terima kasih, meminta maaf, kebahagiaan atau kesenangan, dan mengeluh. Tindak tutur ekspresif merupakan fokus yang dipilih pada penelitian ini. Pemilihan ini dilakukan dengan pertimbangan atau alasan bahwa tindak tutur berkaitan dengan analisis ujaran dalam kaitannya dengan perilaku penutur suatu bahasa dengan penuturnya yang langsung berkaitan dengan manusia lain. Kajian tindak tutur merupakan penelitian yang cukup menarik untuk diteliti. Hal ini terbukti dengan banyaknya laporan penelitian yang membahas kajian tindak tutur. Laporan penelitian yang ditemukan peneliti terkait kajian tindak tutur sangat beragam. 
Pada penelitian ini penulis membatasi tindak tutur ekspresif menurut teori Chaer, yakni berupa tindak tutur ekspresif memuji, mengucapkan terima kasih, meminta maaf, kebahagiaan atau kesenangan dan mengeluh. Salah satu teori yang diungkapkan Chaer (2010) yaitu "Mengucapkan Selamat" tidak penulis gunakan, karena sebelum melakukan penelitian atau memilih masalah penulis terlebih dahulu penulis menonton dan mengamati film tersebut agar mengetahui tuturan-tuturan apa saja yang akan dianalisis. Setelah melakukan proses tersebut penulis baru mengetahui bahwa tindak tutur mengucapkan selamat belum atau tidak ditemukan dalam film Kehormatan di Balik Kerudung, sehingga penulis membatasi penelitian tindak tutur ekspresifnya berupa tindak tutur ekspresif memuji, mengucapkan terima kasih, meminta maaf, kebahagiaan atau kesenangan, dan mengeluh.

Film Kehormatan di Balik Kerudung merupakan film berisi tentang percintaan, kesedihan, dan kesetiaan. Banyak hal yang dapat dipelajari dari film yang disutradarai oleh Tya Subiakto Satrio ini, mulai dari pengorbanan, perjuangan hingga kebahagiaan. Film yang dibintangi oleh Donita, Ussy Sulistiawati, dan Andika Pratama sangatlah menarik dan bisa dijadikan sebagai contoh hidup, karena tidak semua manusia mampu menerima sosok wanita lain dalam rumah tangganya dengan alasan apapun. Namun, film Kehormatan di Balik Kerudung ini mengajarkan bahwa emosi tidak mampu menjadikan segalanya indah. Dengan hati yang ikhlas Sofia nama Ussy dalam film tersebut menerima Donita sebagai Syahdu untuk menjadi madunya dengan alasan bahwa Syahdu menanggung sakit yang berlarut. Dari hal tersebut saja sudah tergambar ada tindak tutur ekspresif yang dilakukan oleh Sofia terhadap Syahdu. Bukan hanya itu toleransi yang kuat antarsesama manusia merupakan salah satu sifat terpuji yang seharusya dimiliki setiap manusia.

Berdasarkan latar belakang, maka peneliti ingin melakukan penelitian dengan judul "Tindak Tutur Ekspresif dalam Film Kehormatan di Balik Kerudung Sutradara Tya Subiakto Satrio". Adapun penelitian yang pernah dilakukan tentang analisis tindak tutur oleh Widyarini (2016) dengan judul "Analisis Tindak Tutur Direktif, Ekspresif, dan Komisif pada Teks Pidato Karangan Siswa Kelas X SMK 2 Muhammadiyah Blora". Hasil dari penelitian terdapat 3 hal yang perlu dibahas. (1) Muncul beberapa bentuk tindak tutur di dalam teks pidato siswa kelas X SMK. (2) Bentuk tindak tutur tersebut meliputi direktif meliputi tuturan: permintaan, 
permohonan, perintah, dan ajakan. Bentuk tindak tutur ekspresif terdiri dari tuturan; permintaan maaf, kebahagiaan, kesedihan, kekecewaan, kebanggaan, kekhawatiran, dan berterima kasih. Bentuk tindak tutur komisif berupa tuturan; ancaman, berjanji, dan menyatakan kesanggupan. (3) Bentuk-bentuk tuturan yang telah ditemukan dan dianalisis serta gambaran maksud dan tujuan si-penutur. Temuan ini menunjukkan bahwa tuturan ancaman dan perintah mendominasi isi dari pidato siswa yang dipengaruhi oleh pengalaman siswa di dalam lingkungan sekolah. Berbeda dengan hasil penelitian tentang tindak tutur ekspresif dalam film Kehormatan di Balik Kerudung yang akan membahas tentang tindak tutur ekspresif menurut Chaer yaitu ekspresi memuji, mengucapkan terima kasih, mengucapkan maaf, mengucapkan kebahagiaan, dan ekspresi mengeluh.

Berdasarkan latar belakang di atas penelitian ini bertujuan untuk mendeskripsikan tindak tutur ekspresif dalam film Kehormatan di Balik Kerudung dengan sutradara Tya Subiakto Satrio. Sedangkan tujuan khusus dari penelitian ini adalah (1) mendeskripsikan wujud tindak tutur ekspresif memuji dalam film Kehormatan di Balik Kerudung; (2) mendeskripsikan wujud tindak tutur ekspresif mengucapkan terima kasih dalam film Kehormatan di Balik Kerudung; (3) mendeskripsikan wujud tindak tutur ekspresif mengucapkan maaf dalam Film Kehormatan di Balik Kerudung; (4) mendeskripsikan wujud tindak tutur ekspresif kebahagiaan dalam film Kehormatan di Balik Kerudung; dan (5) mendeskripsikan wujud tindak tutur ekspresif mengeluh dalam film Kehormatan di Balik Kerudung.

Menurut Brown dan Yule (1983) (dalam Ihsan, 2011:22) menyatakan pragmatik sebagai pendekatan untuk mempelajari bahasa yang melibatkan analisis unsurnya seperti, tatabahasa, kosakata, dan maknanya dengan melihat konteksnya. Dengan kata lain, menganalisis bahasa terutama bahasa lisan seperti percakapan. Pemerhati bahasa harus lebih memperhatikan konteksnya yang menyangkut partisipan, lokasi, waktu, dan topik pembicaraan, tidak hanya unsurunsur linguistik formalnya saja.

Tarigan (2009:16) menyatakan bahwa tindak tutur merupakan gejala individual, bersifat psikologis dan keberlangsungannya ditentukan oleh kemampuan bahasa si penutur dalam menghadapi situasi tertentu dan dilihat pada makna atau arti tindakan dalam tuturannya. Dengan kata lain, kedua belah pihak, yaitu penutur 
dan petutur terlibat dalam suatu tujuan kegiatan yang berorientasi pada tujuan tertentu. Sesuai dengan keterangan tersebut, maka instrumen pada penelitian ini mengacu pada teori tindak tutur.

Chaer (2010:83) lebih lanjut menjelaskan bahwa tindak tutur dalam kajian ilmu pragmatik terdapat tiga, yaitu tindak tutur lokusi, ilokusi, dan perlokusi. Pertama adalah tindak lokusi, yang merupakan tindak dasar tuturan atau menghasilkan suatu ungkapan linguistik yang bermakna. Kedua tindak tutur ilokusi ditampilkan melalui penekanan komunikatif suatu tuturan. Menuturkan untuk membuat suatu pernyataan, tawaran, penjelasan, atau maksud-maksud komunikatif lainnya. Ketiga tindak perlokusi ialah menuturkan dengan asumsi bahwa pendengar akan mengenali akibat yang ditimbulkan.

Menurut Yule (2006:82), tindak tutur merupakan tindakan-tindakan yang ditampilkan lewat tuturan. Sejalan dengan pendapat tersebut Searle (dalam Wijana, 2009:20) tindak tutur adalah hasil dari suatu kalimat dalam kondisi tertentu dan merupakan satuan terkecil dari komunikasi bahasa. Seorang pakar kawakan dalam bidang ini yaitu Leech (dalam Tarigan 2009:45), telah mengklasifikasikan tindak ilokusi berdasarkan kriteria, sebagai berikut: 1. Asertif, yaitu melibatkan pembicaraan pada kebenaran proposisi yang diekspresikan, misalnya: menyatakan, memberitahukan, menyarankan, membanggakan, mengeluh, menuntut, melaporkan. llokusi-ilokusi yang seperti ini cenderung bersifat netral dari segi kesopansantunan, dan dapat dimasukkan ke dalam kategori kolaboratif di atas. Namun demikian. ada beberapa kekecualian, misalnya membanggakan dan menyombongkan yang pada umumnya dianggap tidak sopan secara semantis dan asertif bersifat proposisional. 2. Direktif dimaksudkan untuk menimbulkan beberapa efek melalui tindakan sang penyimak, misalnya: memesan, memerintahkan, memohon, meminta, menyarankan, menganjurkan, menasihatkan. Semua ini sering kali termasuk kedalam kategori kopetitif , dan oleh karena itu terdiri dari suatu kategori ilokusi-ilokusi dimana kesopansantunan yang negatif menjadi penting.

Sebaliknya, beberapa direktif (seperti undangan) pada hakikatnya dianggap sopan. Perlu dicatat bahwa untuk menghilangkan kebingungan dalam pemakaian istilah direktif dalam hubungannya dengan 'direct and indirect illocitions', Leech justru menganjurkan pemakaian istilah impositif bagi ilokusi-ilokusi kompetitif dalam 
kelas ini. 3. Komisif melibatkan pembicara pada beberapa tindakan yang akan datang, misalnya: menjanjikan bersumpah, menawarkan, memanjatkan doa. Semua ini cenderung bersifat konvivial ketimbang kompetitif, dilaksanakan justru lebih memenuhi minat seseorang selain daripada sang pembicara. 4. Ekspresif mempunyai fungsi untuk mengekspresikan mengungkapkan, atau memberitahukan sikap psikologis sang pembicara menuju suatu pernyataan keadaan yang diperkirakan oleh ilokusi; misalnya: mengucapkan terima kasih, mengucapkan selamat, memaafkan, mengampuni, menyalahkan, memuji, menyatakan belasungkawa, dan sebagainya. Seperti juga halnya komisif, maka semua ini cenderung menjadi konvivial karena dianggap sopan. Akan tetapi, sebaliknya juga dapat dibenarkan, misalnya tindak tutur ekspresif seperti 'menyalahkan' dan 'menuduh'. 5. Deklaratif adalah ilokusi yang apabila performansinya berhasil akan menyebabkan korespondensi yang baik antara isi proposisional dengan realitas. Contoh: menyerahkan diri, memecat, membebaskan, membaptis, memberi nama, menamai, mengucilkan, mengangkat, menunjuk, menentukan, menjatuhkan hukuman, memvonis, dan sebagainya.

Penelitian relevan lainnya yang terkait dengan penelitian ini yaitu penelitian yang dilakukan oleh Kurniawati (2014) dengan judul Tindak Tutur Ilokusi Tokoh Utama dalam Film Kehormatan di Balik Kerudung Sutradara Tya Subiyakto dan Relevansinya dengan Pembelajaran Menyimak dan Berbicara di Kelas X SMA. Hasil penelitian ini menunjukkan bahwa film Kehormatan di Balik Kerudung terdapat beberapa macam kategori tindak tutur ilokusi yang meliputi: kategori asertif, kategori direktif, kategori komisif, dan kategori deklaratif. Wujud tuturan yang digunakan tokoh utama adalah tuturan langsung dan tidak langsung. Relevansi antara tindak tutur ilokusi pada film Kehormatan di Balik Kerudung dengan pembelajaran keterampilan menyimak dan berbicara di SMA meliputi: (a) keterampilan menyimak: peserta didik mampu memahami tuturan secara langsung dan tidak langsung melalui tuturan ilokusi yang terdapat pada film dan (b) keterampilan berbicara: peserta didik mampu berbicara dengan tepat dan santun sesuai dengan konteks. Dari hasil penelitian ini menunjukkan bahwa penelitian tentang tindak tutur ekspresif dalam film Kehormatan di Balik Kerudung belum dilakukan penelitian. 


\section{B. Metode Penelitian}

Metode penelitan yang digunakan yaitu metode deskriptif kualitatif. Metode deskriptif kualitatif merupakan proses pemecahan masalah yang diselidiki dengan menggambarkan atau menuliskan keadaan subjek atau objek-objek penelitian (Sugiyono, 2014). Dalam peneltian ini memberikan gambaran tertentu atau aspek kehidupan tertentu dari tokoh yang diteliti, yaitu: mendeskripsikan tindak tutur pada tokoh yang diteliti pada film Kehormatan di Balik Kerudung. Rancangan penelitian deskriptif dipilih karena sesuai dengan karakteristk masalah penelitian, yaitu analisis tindak tutur ekspresif dalam Film Kehormatan di Balik Kerudung.

Langkah-langkah dalam menganalisis data sebagai berikut: a). tahap deskripsi yang diperoleh dihubungkan dengan persoalan, setelah itu dilakukan tahap pendeskripsian karena dalam penelitian ini data yang terkumpul berupa satuan semantik seperti kata-kata, frasa, klausa, kalimat, dan paragraf. b). Tahap klasifikasi, data yang telah dideskripsikan kemudian dikelompokkan menurut kelompoknya masing-masing sesuai dengan permasalahan yang ada. Dalam hal ini dimaksudkan tindak tutur ekspresif berupa tuturan mengucapkan terima kasih, mengucapkan maaf, kebahagiaan, memuji, dan mengeluh. c). Tahap analisis, data yang diklasifikasikan menurut kelompoknya masing-masing dianalisis menurut tindak tutur ekspresif berupa tuturan mengucapkan terima kasih, mengucapkan maaf, kebahagiaan, memuji, dan mengeluh. d). Tahap interpretasi data yaitu upaya penafsiran, pengkajian, dan pemahaman hasil analisis data. e). Tahap evaluasi, data-data yang sudah dianalisis dan diinterpretasikan sebelum ditarik kesimpulan. Data-data harus diteliti dan dievaluasi agar dapat diperoleh penelitian yang dapat dipertanggungjawabkan. f). Tahap kesimpulan, dari hasil evaluasi yang sudah dianalisis data terakhir ditarik kesimpulan dari keseluruhannya.

\section{Hasil Penelitian dan Pembahasan}

\section{Hasil Penelitian}

Hasil penelitian pada Film Kehormatan di Balik Kerudung telah ditemukan 69 data dari keseluruhan, yang telah dilakukan kodefikasi, klasifikasi, dan pengelompokkan berdasarkan jenis tuturan ekpsresifnya. Hal ini membantu peneliti dan memberikan gambaran jelas dalam menganalisis tindak tutur ekspresif. Peneliti 
kemudian melakukan pengidentifikasian data yang termasuk ke dalam bentuk tindak tutur ekspresif dan kodefikasi data yaitu dengan memberikan identitas data. Dengan diberi kodefikasi KDBK/23 (Kehormatan di Balik Kerudung/menit atau waktu tuturan).

Klasifikasi data penelitian ini berupa susunan data yang sudah digolongkan pada reduksi data yaitu berupa tuturan-tuturan ekspresif. Berikut temuan penelitian tentang tindak tutur ekspresif dalam film Kehormatan di Balik Kerudung dengan Sutradara Tya Subiakto Satrio.

Tabel 1. Klasifikasi Persentase Tuturan Ekspresif dalam Film Kehormatan di Balik Kerudung dengan Sutradara Tya Subiakto Satrio

\begin{tabular}{ccc}
\hline No. & Jenis Tuturan & Persentase \\
\hline 1 & Tuturan Ekspresif & $60 \%$ \\
\hline 2 & Tuturan Jenis Lain & $40 \%$ \\
& & \\
\hline
\end{tabular}

Hasil klasifikasi di atas menunjukkan bahwa dalam Film Kehormatan di Balik Kerudung terdapat banyak tuturan ekspresif, terbukti bahwa persentase tuturan ekspresif lebih besar (60\%) dari pada tuturan jenis lainnya (40\%). Penyajian data dalam penelitian kualitatif dapat dilakukan dalam bentuk bagan, uraian singkat, serta kategori dan sejenisnya. Dengan mendisplay data, dapat memudahkan peneliti memahami apa yang terjadi dan membuat rencana kerja selanjutnya berdasarkan apa yang sudah dipahami. Penyajian hasil analisis tindak tutur ekspresif dalm film Kehormatan di Balik Kerudung, sebagai berikut:

Tabel 2. Hasil Analisis Jenis Tindak Tutur Ekspresif dalam Film Kehormatan di Balik Kerudung Karya PT Kharisma Starvision Plus

\begin{tabular}{lllc}
\hline No. & Jenis Tindak Tutur Ekpresif & \multicolumn{1}{c}{ No. Data } & Jumlah \\
\hline 1 & Mengucapkan Terima Kasih & $5,18,19,22,23,47,48,49,57,64,67$ & 11 \\
& & & \\
2 & Mengucapkan Maaf & $1,17,20,24,30,31,33,35,36,38,45,50,52,56$, & 19 \\
3 & Kebahagiaan/Kesenangan & $58,59,62,66,69$ & \\
4 & Memuji & $2,8,9,10,12,16,26,28,41,42,43,53,60,61$ & 14 \\
5 & Mengeluh & $11,13,14,15,21,29,3234,37$, & 8 \\
& & $40,44,46,54,55,63,65,68$ & 17 \\
\hline
\end{tabular}

\section{Pembahasan}

a. Tindak Tutur Ekspresif Mengucapkan Terima Kasih

Tuturan ekspresif atau tindak tutur ekspresif merupakan tindak tutur yang dimaksudkan oleh penuturnya agar ujarannya dapat diartikan sebagai evaluasi Silampari Bisa: Jurnal Penelitian Pendidikan Bahasa Indonesia, Daerah, dan Asing Vol. 1, No. 1, 2018 
tentang hal yang disebutkan dalam tuturan tersebut. Bentuk tuturan semacam ini memiliki fungsi untuk mengekspresikan atau mengungkapkan sikap psikologis penutur terhadap petuturnya.

Adapun beberapa fungsi tuturan ekspresif yang terkadung dalam sebuah ujaran yang ditemukan dalam film Kehormatan di Balik Kerudung yang disampaikan oleh penutur kepada petuturnya, yakni dapat berfungsi mengucapkan terima kasih, mengucapkan maaf, kebahagiaan, memuji, dan kesedihan. Tuturan ekspresif ucapan terima kasih merupakan tindak tutur yang biasanya terjadi karena beberapa faktor yaitu, dikarenakan mitra tutur atau petuturnya bersedia melakukan apa yang diminta oleh penutur, atau dikarenakan kebaikan hati penutur yang telah memberikan sesuatu kepada petutur atau penutur menghargai atas apa yang telah dilakukan petutur. Berikut ini adalah contoh tuturan ekspresif mengucapkan terima kasih dalam film Kehormatan di Balik Kerudung dalam konteks Syahdu (penutur) mengucuapkan terima kasih kepada Andi (petutur) karena telah menjemputnya di stasiun dan mengantarkannya ke rumah Kakek.

Syahdu : "Terima kasih ya Ndi".

Andi : "Ya". (Data 5 KDBK/11:16)

Pada data (5) KDBK/11:16 di atas terdapat percakapan berupa tuturan ekspresif mengucapkan terima kasih atara Syahdu (penutur) dan Andi (petutur) yang bertujuan untuk menyampaikan sesuatu atas tindakan bermanfaat yang telah petutur lakukan terhadap penutur. Tuturan "Terima kasih ya Ndi" disampaikan oleh Syahdu (penutur) kepada Andi (petutur) berupa bentuk ucapan, penghargaan serta memuji atas apa yang telah Andi (petutur) lakukan terhadap Syahdu (petutur) dan merupakan sifat terpuji. Sejalan dengan pendapat Chaer (2010:29) yang menyatakan bahwa tuturan ekspresif ucapan terima kasih merupakan tindak tutur yang biasanya diucapkan penutur atas pertolongan atau perlakuan baik petutur terhadap dirinya. Hal tersebut bisa juga terjadi karena beberapa faktor di antaranya, yaitu dikarenakan mitra tutur atau petuturnya bersedia melakukan apa yang diminta oleh penutur, atau dikarenakan kebaikan hati penutur yang telah memberikan sesuatu kepada petutur atau penutur menghargai atas apa yang telah dilakukan petutur. 
b. Tuturan Ekspresif Mengucapkan Maaf

Tuturan ekspresif mengucapkan maaf merupakan tindak tutur yang terjadi karena beberapa faktor, misalnya karena perasaan tidak enak penutur terhadap petutur, perasaan bersalah penutur terhadap petutur, atau bisa karena permintaan petutur. Berikut ini adalah contoh tuturan ekspresif mengucapkan maaf dalam film Kehormatan di Balik Kerudung dalam konteks Syahdu (penutur) menangis karena dilarang kakek mendekati Ifan.

Syahdu : "Tidak pernah terbesit dalam pikiran Syahdu untuk dekat dengan Ifan nek, tapi Syahdu tidak bisa membohongi diri sendiri kalau Ifan adalah laki-laki baik. Syahdu tidak bisa nek, lebih baik Syahdu pergi dari pada Syahdu mencoreng nama baik kakek dan nenek. Maafkan Syahdu Nek" (Data 17 $\mathrm{KDBK} / 30: 36)$

Pada data (17) KDBK/30:36 di atas terdapat percakapan berupa tindak tutur ekspresif mengucapkan maaf oleh Syahdu (penutur) kepada Nenek (petutur). Tuturan "Tidak pernah terbesit dalam pikiran Syahdu untuk dekat dengan Ifan nek, tapi Syahdu tidak bisa membohongi diri sendiri kalau Ifan adalah laki-laki baik. Syahdu tidak bisa Nek lebih baik Syahdu pergi dari pada Syahdu mencoreng nama baik kakek dan nenek. Maafkan Syahdu Nek" merupakan sikap bersalah Syahdu (penutur) yang disampaikan kepada kakek dan nenek bahwa Syahdu sudah mencintai Ifan dan membuat warga kampung membuat gosib tentang dirinya.

Sesuai dengan pendapat Chaer (2010:29) yang menyatakan bahwa tuturan ekspresif mengucapkan maaf merupakan tindak tutur yang terjadi karena beberapa faktor, misalnya karena perasaan tidak enak penutur terhadap petutur, perasaan bersalah penutur terhadap petutur, atau bisa karena permintaan petutur. Melakukan sesuatu tindakan dalam mengatakan sesuatu atau tindak tutur yang dibatasi oleh konvensi sosial dan psikologis penutur merupakan ciri dari tuturan ekspresif berupa tuturan mengucapkan maaf.

Contoh kutipan tersebut terlihat bahwa ada hal yang membuat kakek melarang keras Syahdu untuk berhubungan dengan Ifan. Namun, Syahdu tidak bisa membohongi hati kecilnya jika penutur sangat mencintai Ifan. Dengan terpaksa Syahdu meninggalkan desa tersebut, karena tidak bisa jika terus menerus berada di desa itu, sedangkan kakek dan nenek melarang untuk bertemu dengan Ifan laki- 
laki yang sangat Syahdu (penutur) sayangi. Dengan perasaan sedih Syahdu menyampaikan maaf kepada kakek dan nenek karena harus pulang ke rumah ibunya, agar tidak bertemu dengan Ifan lagi sesuai dengan yang diharapkan kakek dan nenek.

\section{c. Tuturan Ekspresif Kebahagiaan}

Tuturan ekspresif kebahagian merupakan tindak tutur yang terjadi karena beberapa faktor seperti kesenangan, perasaan bahagia, jatuh cinta serta keberuntungan lainnya sehingga muncul psikologis penutur yang bersifat bahagia. Berikut ini adalah contoh tuturan ekspresif kebahagiaan dalam Film Kehormatan di Balik Kerudung dalam konteks Ifan (penutur) mengungkapkan perasaannya kepada Syahdu (petutur).

Ifan : Karena terlalu dalam yang ada hanya ketulusan cinta hidup didasar Hatimu.

Syahdu : "Ifan aku janji aku akan menjaga kebahagiaan yang telah kamu berikan dalam hidupu". (Data $10 \mathrm{KDBK} / 24: 58)$

Pada data $10 \mathrm{KDBK} / 24: 58$ di atas terdapat percakapan berupa tindak tutur ekspresif kebahagiaan antara Ifan (penutur) dan Syahdu (petutur). Tuturan "Ifan aku janji aku akan menjaga kebahagiaan yang telah kamu berikan dalam hidupu" merupakan ungkapan kebahagiaan yang dirasakan Syahdu (petutur) bersama Ifan (penutur). Kebahagiaan itu muncul karena antara Ifan (penutur) dan Syahdu (petutur) merasakan senang atau suka satu sama lain dan berjanji akan menjaga kebahagiaan yang telah penutur berikan sehingga petutur mengungkapkan tuturan berupa kebahagiaan.

Contoh kutipan tentang tindak ekspresif kebahagiaan menggambarkan tentang perasaan bahagia, sejalan dengan pendapat Chaer (2010:29) tuturan ekspresif kebahagian merupakan tindak tutur yang terjadi karena beberapa faktor seperti kesenangan, perasaan bahagia, jatuh cinta serta keberuntungan lainnya. Sehingga muncul psikologis penutur yang bersifat kebahagiaan.

\section{d. Tuturan Ekspresif Memuji}

Tuturan ekspresif memuji atau tindak tutur ekspresif memuji merupakan tindak tutur yang terjadi karena beberapa faktor, yakni dikarenakan kondisi dari 
petutur yang sesuai dengan kenyataan yang ada karena penutur ingin menyenangkan hati petutur, karena penutur ingin melegakan hati petutur, dan karena penutur ingin merayu petutur atau karena perbuatan terpuji yang dilakukan petutur. Berikut ini adalah contoh tuturan ekspresif memuji dalam Film Kehormatan di Balik Kerudung dalam Konteks Ifan (penutur) bertemu dengan Syahdu (petutur) di Stasiun namun belum saling mengenal.

Ifan : : "Mbak cantik ya. Saya foto boleh nggak saya wartawan loh nanti saya masukin ke majalah saya. Hmm okay. Mbak mengapa terlihat tegang? Apa saya aneh? Anggap saja saya ini teman lama, karena kita bertemu Uma sekali ini saja"

Syahdu : Mengapa mas berbicara seperti itu, bukankah sekarang dunia seakan sempit. Cara bisa dipaksakan oleh waktu Mas. (Data 2 KDBK/05:27)

Pada data 2 KDBK/05:27 di atas terdapat percakapan berupa tuturan ekpresif memuji antara Ifan (petutur) dan Syahdu (petutur). Tuturan merupakan tuturan yang diucapkan Ifan (penutur) kepada Syahdu (petutur) ketika berada di stasiun sebelum kereta api tiba. Ifan benar-benar mengagumi paras cantik yang dimiliki Syahdu. Penutur memuji dengan kenyataan yang ada, karena apa yang dilihat sesuai dengan kenyataan. Syahdu (petutur) memiliki wajah yang cantik, sehingga Ifan (petutur) menuturkan tuturan ekspresif memujinya. Tuturan tersebut bukan untuk menggombali ataupun berpura-pura, namun bertujuan untuk menyampaikan informasi sesuai dengan kenyataan. Sesuai dengan pendapat Chaer (2010:29), tuturan ekspresif memuji atau tindak tutur ekspresif memuji merupakan tindak tutur yang terjadi karena beberapa faktor, yakni dikarenakan kondisi dari petutur yang sesuai dengan kenyataan yang ada, karena penutur ingin menyenangkan hati petutur, karena penutur ingin melegakan hati petutur, dan karena penutur ingin merayu petutur atau karena perbuatan terpuji yang dilakukan petutur.

\section{e. Tuturan Ekspresif Mengeluh}

Tuturan ekspresif atau tindak tutur ekspresif mengeluh merupakan tindak tutur yang terjadi karena ingin mengungkapkan rasa sedih, susah, kecewa yang disebabkan oleh penderitaan, kesakitan, ataupun kenyataan yang tidak sesuai dengan harapan. Hal ini sejalan dengan pendapat Chaer (2010:29) yang 
menyatakan bahwa tuturan ekspresif atau tindak tutur ekspresif mengeluh merupakan tindak tutur yang terjadi karena ingin mengungkapkan rasa sedih, susah, kecewa yang disebabkan oleh penderitaan, kesakitan, ataupun kenyataan yang tidak sesuai dengan harapan.

Berikut ini adalah contoh tuturan ekspresif mengeluh dalam Film Kehormatan di Balik Kerudung dalam konteks Kakek memanggil Syahdu dan melarang Syahdu mendekati Ifan.

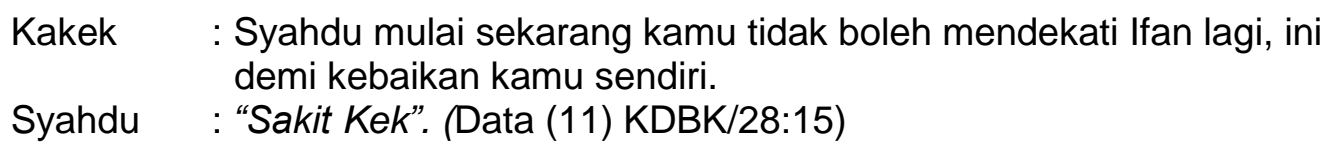

Pada data (11) KDBK/28:15 di atas terdapat percakapan berupa tindak tutur ekspresif mengeluh antara Syahdu (penutur) dan Kakek (petutur). Tuturan "Sakit Kek" dituturkan Syahdu kepada Kakek karena Kakek melarang Syahdu untuk mendekati Ifan. Oleh karena perasaan sedih tersebut, maka penutur kecewa atas sikap yang dilakukan kakek terhadapnya sehingga penutur menuturkan tindak tutur ekspresif mengeluh kepada Kakek (petutur).

Berikut contoh kutipan dengan konteks Syahdu menangis ketika menelepon Ifan karena mengetahui kakek melarang hubungannya.

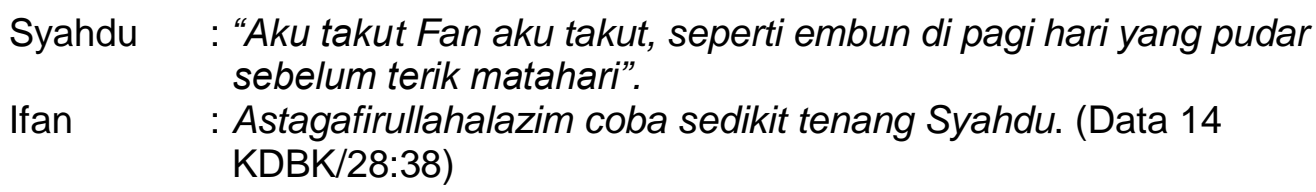
sebelum terik matahari".

Ifan : Astagafirullahalazim coba sedikit tenang Syahdu. (Data 14 KDBK/28:38)

Pada data (14) KDBK/28:38 di atas terdapat percakapan berupa tuturan ekspresif mengeluh antara Syahdu (penutur) dan Ifan (petutur). Tuturan "Aku takut Fan aku takut, seperti embun di pagi hari yang pudar sebelum terik matahari" dituturkan Syahdu (penutur) kepada Ifan (petutur) melalui telepon. Syahdu merasa ketakutan akan kelanjutan hubungannya mengetahui bahwa Kakek melarang keras hubungannya dengan Ifan. Perasaan sedih, kecewa, dan marah membuat Syahdu mengeluhkan semuanya karena semua tidak sesuai dengan yang diharapkannya. 


\section{Simpulan}

Berdasarkan hasil penelitian dan pembahasan, maka dapat menyimpulkan bahwa pada penelitian ini ditemukan jenis tindak tutur dan fungsi tuturan ekspresif berupa tuturan ekspresif: a) memuji dalam konteks: memuji kecantikan dan ketampanan yang dimiliki petutur, terkesan dengan pakaian, dan wewangian yang petutur kenakan; b) mengucapkan terima kasih dengan ciri: mengucapan terima kasih karena perbuatan baik yang sudah dilakukan petutur, mengucapkan terima kasih atas kenikmatan yang Allah berikan, mengucapkan terima kasih karena merasa merepotkan; c) mengucapkan maaf dengan ciri: karena telah mengecewakan petutur, karena tidak menepati janji, mengucapkan maaf atas perlakuan kasar dan tidak menyenangkan, serta berbuat kesalahan; d) kebahagiaan dengan ciri: situasi yang membuat nyaman, bersyukur atas apa yang dimiliki, tersenyum indah, saling menyukai, dan dikaruniai anak; serta e) mengeluh dengan konteks: perasaan sedih karena ditinggal menikah, perasaan sakit karena dilarang menikah, dan dikecewakan, serta diberi cobaan atau halangan dan rintangan.

\section{Daftar Pustaka}

Chaer, Abdul. (2010). Kesantunan Berbahasa. Jakarta: Rineka Cipta.

Chaer, Abdul. (2010). Sosiolingiustik: Perkenalan Awal. Jakarta: Rineka Cipta.

Ihsan, Diemroh. (2011). Pragmatik, Analisis Wacana, dan Guru Bahasa. Hak Cipta: Universitas Sriwijaya.

Kurniawati, Endah Yuli. (2014). Tindak Tutur llokusi Tokoh Utama dalam Film Kehormatan di Balik Kerudung Sutradara Tya Subiyakto dan Relevansinya dengan Pembelajaran Menyimak dan Berbicara di Kelas X SMA. http://download. portalgaruda.org/article.php?article $=372423 \&$ val=609\&title $=$ TINDAK\%20TUTUR\%20ILOKUSI\%20TOKOH\%20UTAMA\%20DALAM\%20 FILM\%20KEHORMATAN\%20DI\%20BALIK\%20KERUDUNG\%20SUTRAD ARA\%20TYA\%20SUBIYAKTO\%20\%20DAN\%20RELEVANSINYA\%20DEN GAN\%20PEMBELAJARAN\%20MENYIMAK\%20\%20DAN\%20BERBICARA \%20DI\%20KELAS\%20X\%20SMA. Jurnal diakses pada 2 Januari 2018.

Levinson, Stephen C. (1983). Pragmatics. Cambridge: Cambridge University Press. 
Sugiyono. (2014). Metode Penelitian Kuantitatif, Kualitatif, dan Kombinasi (Mixed Method). Bandung: Alfabeta.

Tarigan, Henry Guntur. (2009). Pengajaran Pragmatik. Edisi Revisi. Bandung: Angkasa.

Widyarini, Nur Rachmi. (2016). Analisis Tindak Tutur Direktif, Ekspresif, dan Komisif pada Teks Pidato Karangan Siswa Kelas X SMK 2 Muhammadiyah Blora. Skripsi. http://eprints.ums.ac.id/48908/1/NASKAH\%20PUBLIKASI.pdf.

Wijana, I Dewa Putu. (2009). Dasar-Dasar Pragmatik. Yogyakarta: Andi Yogyakarta.

Yule, George. (2006). Pragmatik. Cetakan Pertama. Yogyakarta: Pustaka Pelajar. 